\title{
66. Notes on the Rich Chloride Content and the Osmotic Pressure of Metasequoia glyptostroboides
}

\author{
By Hideo Takada and Susumu Nagai \\ Biological Department, Institute of Polytechnics, Osaka City University, \\ Osaka \\ (Comm. by H. Kihara, M.J.A., June 12, 1953)
}

The regulatory and periodic fluctuations in the osmotic pressure is almost solely affected by sugars so as to lead to the conclusion that non-electrolytes are principally responsible for the variations in the osmotic pressure ${ }^{3 ; 4(4) 69910) 11114) 17}$. Sugar fractions in the osmotic pressure in conifers are very much higher than those in other plants, either woody or herbaceous, whereas the salts in the cell sap usually remain at low and mostly constant level. In this respect an opposite relationship was found with halophytes, whose salt fractions were much larger, sometimes occupying nearly 80 per cent. Precedent investigations on the salt fractions in the osmotic pressure have not so far been detailed enough, though chemical analysis by $\mathrm{Knodel}^{5)}$ on the cell sap of Picea excelsa resulted in the evidence that the chloride fraction was 4 to 5 per cent in it.

Authors are interested in seeking for some physiological aspects cencerning the integrating and comparative studies on the species belonging to Taxodiaceae, with special reference to Metasequoia glyptostroboides $\mathrm{Hu}$ et Cheng, which was recently found living in China ${ }^{788}$ and is now planted in many places around the Pacific. The present work was conducted as an approach to the fundamental features of water relations in the above-mentioned species of conifers. Authors would like to express their indebtedness to Professor Shigeru Miki who founded this study and gave valuable advice on it.

\section{Materials and Methods}

Samples from 16 species of conifers were collected at five different localities, viz. Kisaichi (Botanical Garden of Osaka City University, Osaka Pref.), Kyoto (Botanical Garden of Kyoto University), Ashiya (Hyogo Pref.), Hirai (Hyogo Pref.) and Mt. Rokko (Botanical Garden at the altitude of $830 \mathrm{~m}$ ) during July to November, 1952. Metasequoia alone growing some 4 to $5 \mathrm{~m}$ high, was much younger in tree ages as compared with other species.

Osmotic pressure of the cell saps expressed from the needles 
was determined cryoscopically by essentially the same methods described by Walter ${ }^{1618)}$, as mentioned in previous papers ${ }^{12) 13}$. Quantitative determination of chlorine was made by the microtitration with $\mathrm{N} / 100$ silver nitrate and M/100 ammonium thiocyanate using $0.5 \mathrm{ml}$ of the expressed sap for each aliquot. Among the presumed chemical components of the cell sap, potassium ion was qualitatively detected by the cobalt nitrite procedure while the presence of sodium was hardly proved by the uranyl-zinc-acetate method. Therefore, the estimated partial osmotic pressure due to the chloride fraction was expressed in atmospheres as based on $\mathrm{KCl}$ and also on $\mathrm{NaCl}$, the comparison of the chloride fraction in the osmotic pressure of conifers and that of halophytes also being enabled. Water content of materials was determined by drying for 48 hours at $98^{\circ} \mathrm{C}$ and was calculated as per cent based on dry weight.

\section{Results and Discussion}

The results of these experiments are summarized in Table I. One of the most surprising evidences can be distinguished in the records that the chloride fraction in the osmotic pressure of cell sap is markedly higher in Metasequoia than in other conifers, despite the similarities in total osmotic pressure and water content. The chloride fractions in the cell sap of the species belonging to Taxodiaceae (except Metasequoia) are also somewhat higher than in the cases of Pinaceae. The differences among them are, however, too small to make decisive evaluations.

Addition of the chloride salts to the soil usually caused an increase in the chloride fraction of the expressed saps. In many cases of the plant species growing immediately adjacent together in a small restricted area of the locality, however, showed the changes in the cell saps only independently to each other according to the soil nutrients. Therefore, this diversity in the chloride fraction is likely to originate in the inherent nature of the respective species.

Facilitating a comparison of the chloride fraction, even the percentage of chloride fraction in total osmotic pressure of Metasequoia is a half or a fourth as much as that of halophyte. Though a considerable amount of sodium is present in halophytes, being mostly dissolved as sodium chloride in the cell sap, sodium is hardly detectable in conifers. Wallace and his co-workers ${ }^{15)}$ observed on Pinus virginiana and Juniperus communis that the sodium content was lower than potassium. They also concluded that those conifers 
Table I

\begin{tabular}{|c|c|c|c|c|c|c|c|c|c|c|c|}
\hline \multirow{3}{*}{ Name } & \multirow{3}{*}{ Locality } & \multirow{3}{*}{ Date } & \multirow{3}{*}{$\begin{array}{c}\text { Time } \\
\text { of } \\
\text { day }\end{array}$} & \multirow{3}{*}{$\underset{{ }^{\circ} \mathrm{C}}{\operatorname{Air}}$} & \multirow{3}{*}{$\begin{array}{l}\text { Expo- } \\
\text { sure } \\
\text { to } \\
\text { sun- } \\
\text { light }\end{array}$} & \multirow{3}{*}{$\begin{array}{c}\text { Water } \\
\text { con- } \\
\text { tent } \\
\%\end{array}$} & \multirow{3}{*}{$\begin{array}{l}\text { Os- } \\
\text { motic } \\
\text { value } \\
\text { atm. }\end{array}$} & \multicolumn{4}{|c|}{ Chloride fraction } \\
\hline & & & & & & & & as $\mathrm{K}$ & $\mathrm{Cl}$ & as $\mathrm{N}$ & $\mathrm{NaCl}$ \\
\hline & & & & & & & & atm. & $\%$ & atm. & $\%$ \\
\hline \multirow{6}{*}{$\begin{array}{l}\text { Metasequoia } \\
\quad \text { glyptostroboides }\end{array}$} & \multirow{3}{*}{ Kisaichi } & \multirow{3}{*}{$28-7$} & 9 & 29 & \pm & $\begin{array}{l}282 \\
293 \\
\end{array}$ & $\begin{array}{l}15.8 \\
15.4 \\
\end{array}$ & $\begin{array}{l}3.4 \\
4.2 \\
\end{array}$ & $\begin{array}{l}22 \\
27 \\
\end{array}$ & $\begin{array}{l}2.6 \\
3.2\end{array}$ & $\begin{array}{l}17 \\
21\end{array}$ \\
\hline & & & 12 & 34 & + & $\begin{array}{l}280 \\
297\end{array}$ & $\begin{array}{l}16.0 \\
15.6\end{array}$ & $\begin{array}{l}1.8 \\
2.2\end{array}$ & $\begin{array}{l}11 \\
14\end{array}$ & $\begin{array}{l}1.4 \\
1.7\end{array}$ & $\begin{array}{r}9 \\
11\end{array}$ \\
\hline & & & 16 & 31 & \pm & $\begin{array}{l}261 \\
263\end{array}$ & $\begin{array}{l}15.8 \\
15.6\end{array}$ & $\begin{array}{l}3.3 \\
3.9\end{array}$ & $\begin{array}{l}21 \\
25\end{array}$ & $\begin{array}{l}2.5 \\
3.0\end{array}$ & $\begin{array}{l}16 \\
19\end{array}$ \\
\hline & Hirai & $12-8$ & $\begin{array}{r}6 \\
14\end{array}$ & $\begin{array}{l}20 \\
31\end{array}$ & $\bar{t}$ & $\begin{array}{l}385 \\
307\end{array}$ & $\begin{array}{l}10.0 \\
13.2\end{array}$ & $\begin{array}{l}2.5 \\
3.2\end{array}$ & $\begin{array}{l}25 \\
24\end{array}$ & $\begin{array}{l}1.9 \\
2.4\end{array}$ & $\begin{array}{l}19 \\
18\end{array}$ \\
\hline & \multirow{2}{*}{ Kisaichi } & $19-9$ & 11 & 20 & \pm & $\begin{array}{l}221 \\
231 \\
\end{array}$ & $\begin{array}{l}16.1 \\
15.8\end{array}$ & $\begin{array}{l}3.9 \\
4.2 \\
\end{array}$ & $\begin{array}{l}24 \\
26 \\
\end{array}$ & $\begin{array}{l}3.0 \\
3.2 \\
\end{array}$ & $\begin{array}{l}19 \\
20 \\
\end{array}$ \\
\hline & & $4-11$ & $\begin{array}{l}10 \\
14 \\
\end{array}$ & $\begin{array}{l}21 \\
21\end{array}$ & - & $\begin{array}{l}227 \\
221 \\
\end{array}$ & $\begin{array}{l}17.6 \\
18.6 \\
\end{array}$ & $\begin{array}{l}6.3 \\
6.3 \\
\end{array}$ & $\begin{array}{l}36 \\
34 \\
\end{array}$ & $\begin{array}{l}4.8 \\
4.8 \\
\end{array}$ & $\begin{array}{l}27 \\
26 \\
\end{array}$ \\
\hline $\begin{array}{l}\text { Cryptomeria } \\
\text { japonica }\end{array}$ & Ashiya & $14-8$ & $\begin{array}{r}5 \\
14 \\
21 \\
\end{array}$ & $\begin{array}{l}23 \\
33 \\
28\end{array}$ & 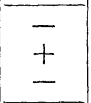 & $\begin{array}{l}210 \\
177 \\
220\end{array}$ & $\begin{array}{l}13.8 \\
15.2 \\
14.7 \\
\end{array}$ & $\begin{array}{l}1.4 \\
1.4 \\
0.8 \\
\end{array}$ & $\begin{array}{r}10 \\
9 \\
5\end{array}$ & \begin{tabular}{l|}
1.1 \\
1.1 \\
0.6 \\
\end{tabular} & $\begin{array}{l}8 \\
7 \\
4\end{array}$ \\
\hline $\begin{array}{l}\text { Sequoia } \\
\text { sempervirens }\end{array}$ & Kyoto & $24-9$ & 11 & 24 & \pm & $\begin{array}{l}151 \\
146 \\
\end{array}$ & $\begin{array}{l}18.8 \\
17.3 \\
\end{array}$ & $\begin{array}{l}1.1 \\
1.1 \\
\end{array}$ & $\begin{array}{l}6 \\
6 \\
\end{array}$ & $\begin{array}{l}0.8 \\
0.8 \\
\end{array}$ & $\begin{array}{l}4 \\
5 \\
\end{array}$ \\
\hline $\begin{array}{l}\text { Taxodium } \\
\text { distichum }\end{array}$ & Kisaichi & $28-7$ & $\begin{array}{r}9 \\
12 \\
15 \\
\end{array}$ & $\begin{array}{l}29 \\
34 \\
31 \\
\end{array}$ & $\begin{array}{l}+ \\
+ \\
+\end{array}$ & $\begin{array}{l}201 \\
187 \\
267 \\
\end{array}$ & $\begin{array}{l}16.8 \\
18.7 \\
17.4 \\
\end{array}$ & $\begin{array}{l}1.1 \\
0.8 \\
0.9\end{array}$ & $\begin{array}{l}7 \\
4 \\
5\end{array}$ & \begin{tabular}{|l|}
0.8 \\
0.6 \\
0.7 \\
\end{tabular} & $\begin{array}{l}5 \\
3 \\
4\end{array}$ \\
\hline $\begin{array}{l}\text { Glyptostrobus } \\
\text { pensilis }\end{array}$ & Kisaichi & $28-7$ & $\begin{array}{r}9 \\
12 \\
15 \\
\end{array}$ & $\begin{array}{l}29 \\
34 \\
31 \\
\end{array}$ & $\begin{array}{l}+ \\
+ \\
+\end{array}$ & $\begin{array}{l}213 \\
258 \\
234 \\
\end{array}$ & $\begin{array}{l}15.3 \\
15.7 \\
15.6 \\
\end{array}$ & $\begin{array}{l}0.7 \\
0.7 \\
0.7 \\
\end{array}$ & $\begin{array}{l}5 \\
4 \\
4 \\
\end{array}$ & $\begin{array}{l}0.6 \\
0.6 \\
0.5 \\
\end{array}$ & $\begin{array}{l}4 \\
4 \\
3 \\
\end{array}$ \\
\hline \multirow{2}{*}{$\begin{array}{l}\text { Libocedrus } \\
\text { formosana }\end{array}$} & \multirow[b]{2}{*}{ Kisaichi } & $19-9$ & 11 & 20 & + & 185 & 16.5 & 1.3 & 8 & 1.0 & 6 \\
\hline & & $4-11$ & $\begin{array}{l}10 \\
14\end{array}$ & $\begin{array}{l}21 \\
21\end{array}$ & - & $\begin{array}{l}160 \\
146 \\
\end{array}$ & $\begin{array}{l}16.9 \\
17.4 \\
\end{array}$ & $\begin{array}{l}1.9 \\
2.0\end{array}$ & $\begin{array}{l}11 \\
11\end{array}$ & $\begin{array}{l}1.4 \\
1.5 \\
\end{array}$ & $\begin{array}{l}8 \\
9 \\
\end{array}$ \\
\hline $\begin{array}{l}\text { Chamaecyparis } \\
\text { obtusa }\end{array}$ & Hirai & $21-8$ & 12 & 31 & + & 172 & 14.6 & 0.3 & 2 & $\overline{0.2}$ & 1 \\
\hline $\begin{array}{l}\text { Juniperus } \\
\text { chinensis }\end{array}$ & Ashiya & $14-8$ & $\begin{array}{r}5 \\
14 \\
21 \\
\end{array}$ & $\begin{array}{l}20 \\
33 \\
28\end{array}$ & $\overline{+}$ & $\begin{array}{l}197 \\
175 \\
204 \\
\end{array}$ & $\begin{array}{l}13.0 \\
15.1 \\
14.7 \\
\end{array}$ & $\begin{array}{l}0.7 \\
0.4 \\
0.5 \\
\end{array}$ & $\begin{array}{l}5 \\
3 \\
3 \\
\end{array}$ & $\begin{array}{l}0.5 \\
0.3 \\
0.4 \\
\end{array}$ & $\begin{array}{l}4 \\
2 \\
3\end{array}$ \\
\hline $\begin{array}{l}\text { Pinus } \\
\quad \text { thunbergii }\end{array}$ & Ashiya & $14-8$ & $\begin{array}{r}5 \\
14 \\
21 \\
\end{array}$ & $\begin{array}{l}23 \\
33 \\
28 \\
\end{array}$ & + & $\begin{array}{l}205 \\
191 \\
208 \\
\end{array}$ & $\begin{array}{l}12.9 \\
13.9 \\
12.7 \\
\end{array}$ & $\begin{array}{l}0.3 \\
0.1 \\
0.1 \\
\end{array}$ & $\begin{array}{l}2 \\
1 \\
1 \\
\end{array}$ & $\begin{array}{l}0.2 \\
0.1 \\
0.1 \\
\end{array}$ & $\begin{array}{l}2 \\
1 \\
1 \\
\end{array}$ \\
\hline $\begin{array}{l}\text { Pinus } \\
\text { densiflora }\end{array}$ & Kisaichi & $\begin{array}{l}19-9 \\
4-11 \\
\end{array}$ & $\begin{array}{l}11 \\
11\end{array}$ & $\begin{array}{l}20 \\
21\end{array}$ & \pm & $\begin{array}{l}165 \\
155 \\
\end{array}$ & $\begin{array}{l}16.3 \\
17.1 \\
\end{array}$ & $\begin{array}{l}0.3 \\
0.3 \\
\end{array}$ & $\begin{array}{l}2 \\
2 \\
\end{array}$ & $\begin{array}{l}0.2 \\
0.2 \\
\end{array}$ & $\begin{array}{l}1 \\
1\end{array}$ \\
\hline $\begin{array}{l}\text { Pinus } \\
\text { australis }\end{array}$ & Kisaichi & $19-9$ & 11 & 20 & + & 180 & 16.3 & 0.4 & 2 & 0.3 & 2 \\
\hline $\begin{array}{l}\text { Cedrus } \\
\text { deodara }\end{array}$ & Kisaichi & $\begin{array}{l}19-9 \\
4-11 \\
\end{array}$ & $\begin{array}{l}11 \\
11\end{array}$ & $\begin{array}{l}20 \\
21\end{array}$ & \pm & $\begin{array}{l}131 \\
118 \\
\end{array}$ & $\begin{array}{l}24.0 \\
24.8 \\
\end{array}$ & $\begin{array}{l}0.1 \\
1.1 \\
\end{array}$ & $\begin{array}{l}0 \\
4 \\
\end{array}$ & $\begin{array}{l}0.1 \\
0.8\end{array}$ & $\begin{array}{l}0 \\
3 \\
\end{array}$ \\
\hline $\begin{array}{l}\text { Pseudotsuga } \\
\text { japonica }\end{array}$ & Kyoto & $24-9$ & 11 & 24 & - & 172 & 13.0 & 0.3 & 2 & 0.2 & 2 \\
\hline $\begin{array}{l}\text { Larix } \\
\text { leptolepis }\end{array}$ & Mt. Rokko & $21-9$ & 11 & 19 & \pm & $\begin{array}{l}240 \\
257 \\
\end{array}$ & $\begin{array}{l}15.1 \\
13.9 \\
\end{array}$ & $\begin{array}{l}1.2 \\
1.7 \\
\end{array}$ & $\begin{array}{r}8 \\
12 \\
\end{array}$ & $\begin{array}{l}0.8 \\
1.3 \\
\end{array}$ & $\begin{array}{l}5 \\
9 \\
\end{array}$ \\
\hline $\begin{array}{c}\text { Pseudolarix } \\
\text { amabilis }\end{array}$ & Kyoto & $24-9$ & 11 & 24 & + & 201 & 10.4 & 1.1 & 11 & 0.8 & 8 \\
\hline $\begin{array}{l}\text { Abies } \\
\text { sachalinensis }\end{array}$ & Mt. Rokko & $21-9$ & 11 & 19 & + & 189 & 16.6 & 0.5 & 3 & 0.4 & 2 \\
\hline
\end{tabular}

Variations in water content, osmotic value and chloride fraction of samples from 16 species of conifers, which were collected at five different localities during July to November, 1952. Water content, expressed as percentage of dry weight. The estimated partial osmotic value due to the chloride fraction, expressed as atomospheres in terms of $\mathrm{KCl}$ and also of $\mathrm{NaCl}$. 
did not accumulate sodium, even if present in large amounts in the nutrient substrate. Pisek ${ }^{9)}$ who recently worked upon the conifers, Picea excelsa and Pinus cembra found that potassium content of the cell sap was higher in the former $(3.5-7 \mathrm{mg} / \mathrm{ml})$ than in the latter (3.5-5 $\mathrm{mg} / \mathrm{ml})$, while both calcium- and magnesium content was very low in either of the plants examined. Collander ${ }^{12)}$ also reported a remarkable diversity in sodium uptake according to plant species and indicated a greater uniformity in potassium accumulation than the cases of sodium or calcium. Since it has been generally ascertained that potassium ion concentration exceeds chlorine ion concentration in conifers, the excess potassium seems to be accompanied by other anions, the organic acids as well as inorganic.

As known from the data obtained, it was noteworthy that the difference between the maximum and the minimum in the diurnal changes of osmotic pressure was only little in conifers as compared with the cases of some herbs and seashore plants, in which the difference often amounted 3 to 4 atmospheres when they suffered from severe and prolonged wilting in the high noon of summer months. Similar tendency was found also in water content of the needles which showed only a slight diurnal fluctuation, e.g. its extent being mostly less than 50 per cent in water content in the cases of Metasequoia.

In some instances it could not be recognized with certainty that the increase in the diurnal changes of osmotic pressure tended to parallel with the increase in the chloride content of the cell sap. In contrast to the high rate of chloride accumulation in halophytes in the morning, the increment rate in conifers were usually rather low and invariable. For instance, Metasequoia measured at Kisaichi on a cloudless day in midsummer (July 28) showed a definite decrease in the chloride fraction while the total osmotic pressure was increasing in the morning. The decrease in the latter took place thereafter in the afternoon with along the increase in the former. The data at Hirai on August 8 was the only exception in regard to such a fluctuation as mentioned above. In the cell sap of Metasequoia on July 28, exposed to full sunshine, the net of chloride content was lower than in the shaded, but the osmotic pressure was higher in the exposed than in the shaded. Strikingly similar results were obtained also on September 9 at Kisaichi and on September 24 at Kyoto.

Alike the data on Metasequoia, similar phenomena were noticed in the diurnal variation of both the osmotic pressure and the chloride content compared in parallel concerning Phragmites communis and some other strand dune plants as reported previously ${ }^{12) 13)}$. 
It is most probable, therefore, that this features of diurnal variations found on Metasequoia might be common in woody plants as well as herbs, the halophytes being particular exceptions. Since it is implausible to assume that chlorine becomes masked as osmotically inactive substances, chlorine might be, under a certain condition at least, translocated from the leaves. More detailed discussion on the processes and equilibrium in relation to the diurnal variation of chloride content should be made with further progress of investigation on these problems.

\section{Summary}

The osmotic pressure and the chloride content in Metasequoia and some conifers were studied on the expressed cell saps. Cryoscopy and micro-titration were effectively employed for the quantitative determination using only small amount of the material.

The chloride content was remarkably higher in Meta equoia than in other conifers notwithstanding that the differences in total osmotic pressure and water content according to the species were only little. In the cell saps altogether so far tested, sodium was hardly detectable while potassium was found in abundance.

The chloride content seemed, as found in its diurnal variation, to play no important part for the shift of total osmotic pressure in the morning as the chloride content in cell saps almost remained at invariable level, somewhat tending to a decrease therein. Those common trends were most distinct in the cases of Metasequoia among the species investigated here.

\section{References}

1) Collander, R.: Ber. deut. bot. Ges., 55, 74 (1937).

2) Collander, R.: Plant Fhysiol., 16, 691 (1941).

3) Gail, F. W.: Bot. Gaz., 81, 434 (1926).

4) Lewis, F. J. and Tuttle, G. M.: Ann. Bot., 34, 405 (1920).

5) Knodel, H. : Planta, 28, 704 (1938).

6) Meyer, B. S.: Amer. J. Bot., 15, 449 (1928).

7) Miki, S.: Seibutu (Biology), 4, 146 (1949) (in Jap.).

8) Miki, S.: J. Inst. Polytech. Osaka City Univ. Series D, 1, 63 (1950).

9) Pisek, A.: Protoplasma, 39, 9 (1950).

10) Steiner, M.: Jahrb. wiss. Bot., 78, 564 (1933).

11) Steiner, M.: Ergebn. Biol., 17, 564 (1939).

12) Takada, H.: J. Inst. Polytech. Osaka City Univ. Series D, 1, 45 (1950).

13) Takada, H.: J. Inst. Polytech. Osaka City Univ. Series D, 2, 9 (1951).

14) Ulmer, W.: Jahrb. wiss. Bot., 84, 553 (1937).

15) Wallace, A., Toth, S. J., and Bear, F.E.: Soil Sci., 65, 249 (1948).

16) Walter, H.: Handb. biolog. Arbeitsmethoden, XI/4, 353 (1931).

17) Walter, H.: Die Hydratur der Pflanze, Jena (1931).

18) Walter, H.: Ber. deut. bot. Ges., 54, 328 (1936). 